\title{
Bacillus hemicentroti sp. nov., a moderate halophile isolated from a sea urchin
}

\author{
Correspondence \\ Yi-Guang Chen \\ mchenjsu@yahoo.com.cn \\ Wen-Jun Li \\ wjli@ynu.edu.cn
}

\author{
Yi-Guang Chen, ${ }^{1}$ Yu-Oin Zhang, ${ }^{2}$ Jian-Wu He, ${ }^{1}$ Hans-Peter Klenk, ${ }^{3}$ \\ Jian-Qing Xiao, ${ }^{1}$ Hong-Yi Zhu, ${ }^{1}$ Shu-Kun Tang ${ }^{4}$ and Wen-Jun $\mathrm{Li}^{4,5}$ \\ ${ }^{1}$ College of Biology and Environmental Sciences, Jishou University, Jishou 416000, PR China \\ ${ }^{2}$ Institute of Medicinal Biotechnology, Chinese Academy of Medical Sciences \& Peking Union \\ Medical College, Beijing 100050, PR China \\ ${ }^{3}$ Deutsche Sammlung von Mikroorganismen und Zellkulturen, D-38124 Braunschweig, Germany \\ ${ }^{4}$ The Key Laboratory for Microbial Resources of the Ministry of Education, PR China, and \\ Laboratory for Conservation and Utilization of Bio-Resources, Yunnan Institute of Microbiology, \\ Yunnan University, Kunming 650091, PR China \\ ${ }^{5}$ Guangdong Key Laboratory of Marine Materia Medica, South China Sea Institute of Oceanology, \\ Chinese Academy of Sciences, Guangzhou 510301, PR China
}

The genus Bacillus, in the phylum Firmicutes, is a large collection of aerobic or facultatively anaerobic, rod-shaped, endospore-forming bacteria and is widely distributed in the environment. The genus is heterogeneous and contains several phylogenetic groups on the basis of 16S rRNA gene sequence analysis (Ash et al., 1991; Stackebrandt \& Liesack, 1993; Nielsen et al., 1994; Ventosa et al., 1998). The genus is attracting interest because its members have great biotechnological potential for the production of compatible solutes or hydrolytic enzymes (Horikoshi, 1999; Margesin \& Schinner, 2001; Arahal \& Ventosa, 2002; Nogi et al., 2005;

The GenBank/EMBL/DDBJ accession number for the 16S rRNA gene sequence of strain JSM $076093^{\top}$ is HM460885.

Two supplementary figures are available with the online version of this paper.
Krulwich et al., 2007). At the time of writing, the genus Bacillus consisted of more than 200 species with validly published names (Euzéby, 2010), including the recently described Bacillus chungangensis (Cho et al., 2010), B. galliciensis (Balcázar et al., 2010), B. halochares (Pappa et al., 2010), B. horneckiae (Vaishampayan et al., 2010), B. marmarensis (Denizci et al., 2010), B. methylotrophicus (Madhaiyan et al., 2010), B. oceanisediminis (Zhang et al., 2010), B. rigui (Baik et al., 2010), B. siamensis (Sumpavapol et al., 2010) and B. trypoxylicola (Aizawa et al., 2010). During an investigation of the diversity of the microbial population of invertebrates inhabiting the South China Sea (Chen et al., 2009a, b, c, 2010; Huang et al., 2009; Xiao et al., 2009), a moderately halophilic, facultatively alkaliphilic, endospore-forming, Gram-staining-positive bacterium, designated strain JSM $076093^{\mathrm{T}}$, was isolated from a sea urchin 
(Hemicentrotus pulcherrimus) collected from Naozhou Island (20 52-56' N 110 33-38' E), China.

For isolation, serial dilutions $(1: 10)$ of sea urchin homogenate were plated on marine agar 2216 (MA; Difco) supplemented with $0-20 \%(\mathrm{w} / \mathrm{v}) \mathrm{NaCl}$ and incubated at $28^{\circ} \mathrm{C}$ for $7-14$ days. A yellow colony on MA supplemented with $10 \%(\mathrm{w} / \mathrm{v}) \mathrm{NaCl}$ was picked and purified. Strain JSM $076093^{\mathrm{T}}$ was maintained on slants of MA supplemented with $3 \%(\mathrm{w} / \mathrm{v}) \mathrm{NaCl}$ (MA3; $\mathrm{pH} 8.0)$, as lyophilized cultures at $4{ }^{\circ} \mathrm{C}$ and in $20 \%$ (v/v) glycerol at $-80{ }^{\circ} \mathrm{C}$. For comparison, Bacillus hwajinpoensis DSM $16206^{\mathrm{T}}$ and Bacillus algicola KCTC $13005^{\mathrm{T}}$ were obtained from the DSMZ and the KCTC, respectively. Unless indicated otherwise, morphological, physiological, molecular and chemotaxonomic studies were performed with cells grown on MA3 at $30{ }^{\circ} \mathrm{C}$.

Strain JSM $076093^{\mathrm{T}}$, B. hwajinpoensis DSM $16206^{\mathrm{T}}$ and B. algicola KCTC $13005^{\mathrm{T}}$ were phenotypically characterized in this study according to the recommendations of the proposed minimal standards for describing new taxa of aerobic, endospore-forming bacteria (Logan et al., 2009). Cell morphology was examined by phase-contrast microscopy (DM3000, $\times 100$ HCX PL Fluotar oil immersion objective, $\mathrm{Ph} 3$; Leica) with cells grown on MA3 supplemented with $10 \mathrm{mg} \mathrm{MnSO}_{4}$ for $1-7$ days at $30{ }^{\circ} \mathrm{C}$. The Gram-staining and $\mathrm{KOH}$ lysis tests were carried out according to Smibert \& Krieg (1994) and Gregersen (1978), respectively. Flagella and endospores were examined according to the methods of Leifson and SchaefferFulton, respectively (Smibert \& Krieg, 1994). Growth in the absence of $\mathrm{NaCl}$ was investigated on nutrient agar (NA) and in nutrient broth (NB) prepared according to the formula of Atlas (1993) without the addition of $\mathrm{NaCl}$. Growth with $0.1,0.5$ and $1-30 \%(\mathrm{w} / \mathrm{v}) \mathrm{NaCl}$ (in increments of $1 \% \mathrm{NaCl}$ ) was tested on $\mathrm{NA}$ and in NB. Growth at 4 and $5-55{ }^{\circ} \mathrm{C}$ (in increments of $5{ }^{\circ} \mathrm{C}$ ) and at $\mathrm{pH}$ $5.0-11.0$ (in increments of $0.5 \mathrm{pH}$ units) was tested in NB, using the buffer solutions described by Chen et al. (2007) to adjust the $\mathrm{pH}$. The methyl red and Voges-Proskauer tests and determination of $\mathrm{H}_{2} \mathrm{~S}$ production from L-cysteine, aesculin hydrolysis, indole production, nitrate and nitrite reduction, glucose oxidation/fermentation and phenylalanine deaminase and urease activities were performed as described by Smibert \& Krieg (1994). Hydrolysis of casein, cellulose, DNA, gelatin, hypoxanthine, starch, Tweens 20, 40, 60 and 80 and xanthine was determined as described by Cowan \& Steel (1965). Growth under anaerobic conditions was determined on MA supplemented with $0.5 \%$ $(\mathrm{w} / \mathrm{v})$ glucose and with or without $0.1 \%(\mathrm{w} / \mathrm{v})$ nitrate using the GasPak Anaerobic System (BBL), according to the manufacturer's instructions. Determination of acid production from carbohydrates and utilization of carbon and nitrogen sources was performed as described by Ventosa et al. (1982). Observation of motility and tests for catalase and oxidase activities were detected as described previously (Chen et al., 2007). Other enzyme activities were assayed using API ZYM strips (bioMérieux), according to the manufacturer's instructions except for the preparation of inocula with $5 \%(\mathrm{w} / \mathrm{v}) \mathrm{NaCl}$. All physiological and biochemical tests were repeated three times.

Cells of strain JSM $076093^{\mathrm{T}}$ were Gram-staining-positive, endospore-forming, non-motile, moderately halophilic, facultatively alkaliphilic rods, with optimum growth occurring with $5-8 \%(\mathrm{w} / \mathrm{v}) \mathrm{NaCl}$ and at $\mathrm{pH} 8.0$ and $30-35{ }^{\circ} \mathrm{C}$. Colonies were yellow, flat and opaque with circular margins and were 3-4 $\mathrm{mm}$ in diameter after 3-4 days. The phenotypic properties that differentiate strain JSM $076093^{\mathrm{T}}$ from its closest phylogenetic neighbours are given in Table 1.

Table 1. Characteristics used to distinguish strain JSM $076093^{\top}$ from its closest phylogenetic neighbours

Strains: 1 , JSM $076093^{\mathrm{T}} ; 2$, B. hwajinpoensis DSM $16206^{\mathrm{T}} ; 3, B$. algicola KCTC $13005^{\mathrm{T}}$. All data were obtained from this study unless indicated otherwise. All strains are endospore-forming, Gramstaining-positive rods and positive for catalase, nitrate reduction and hydrolysis of gelatin, starch and Tween 20. All strains are negative for indole and $\mathrm{H}_{2} \mathrm{~S}$ production, nitrite reduction, phenylalanine deaminase, Voges-Proskauer test and hydrolysis of cellulose, DNA, hypoxanthine and xanthine. C, Central; CR, creamy; LY, light yellow; S, swollen; SS, slightly swollen; ST, subterminal; U, unswollen; Y, yellow; + , positive; - , negative.

\begin{tabular}{|c|c|c|c|}
\hline Characteristic & 1 & 2 & 3 \\
\hline Colony colour & $\mathrm{Y}$ & LY & CR \\
\hline Spore position & ST & $\mathrm{C}$ to $\mathrm{ST}$ & ST \\
\hline Sporangium & $\mathrm{U}$ or ss & SS & s \\
\hline \multicolumn{4}{|l|}{$\mathrm{NaCl}(\%, \mathrm{w} / \mathrm{v})$} \\
\hline Range & $0.5-25$ & $0.5-20$ & $0-4$ \\
\hline Optimum & $5-8$ & $2-4$ & 0 \\
\hline \multicolumn{4}{|l|}{$\mathrm{pH}$} \\
\hline Range & $6.0-10.5$ & $6.0-10.0$ & $6.5-10.5$ \\
\hline Optimum & 8.0 & $7.5-8.0$ & $7.5-8.5$ \\
\hline \multicolumn{4}{|l|}{ Temperature $\left({ }^{\circ} \mathrm{C}\right)$} \\
\hline Range & $5-40$ & $10-40$ & $10-45$ \\
\hline Optimum & $30-35$ & $30-35$ & 30 \\
\hline Oxidase & - & + & - \\
\hline Urease & + & - & + \\
\hline Facultatively anaerobic & + & - & - \\
\hline Glucose fermentation & + & - & - \\
\hline Methyl red test & + & - & - \\
\hline \multicolumn{4}{|l|}{ Hydrolysis of: } \\
\hline Aesculin & + & + & - \\
\hline Casein & + & + & - \\
\hline Tween 40 & + & + & - \\
\hline Tween 60 & + & + & - \\
\hline Tween 80 & - & + & - \\
\hline Source ${ }^{\star}$ & Sea urchin & Seawater & Brown alga \\
\hline $\begin{array}{l}\text { DNA G }+ \text { C content } \\
(\mathrm{mol} \%)^{*}\end{array}$ & 38.8 & 40.9 & 37.4 \\
\hline
\end{tabular}

${ }^{*}$ Data for columns 2 and 3 were obtained from Yoon et al. (2004) and Ivanova et al. (2004), respectively. 
Genomic DNA was isolated according to Hopwood et al. (1985) and the G $+\mathrm{C}$ content was determined using HPLC (Mesbah et al., 1989). The 16S rRNA gene sequence was amplified by PCR and sequenced as described by Cui et al. (2001). Primers A 8-27f (5'-CCGTCGACGAGCTCAGAGTTTGATCCTGGCTCAG-3') and B 1523-1504r (5'-CCCGGGTACCAAGCTTAAGGAGGTGATCCAGCCGCA-3') were used. Pairwise sequence similarities were calculated using a global alignment algorithm implemented at the EzTaxon server (Chun et al., 2007). After multiple sequence alignment using CLUSTAL_X (Thompson et al., 1997), phylogenetic analysis was performed using MEGA version 3.1 (Kumar et al., 2004). Distances were calculated using distance options according to Kimura's two-parameter model (Kimura, 1980) and clustering was performed with the neighbour-joining method (Saitou \& Nei, 1987). Maximum-likelihood (Felsenstein, 1981) and maximumparsimony (Kluge \& Farris, 1969) trees were generated using the algorithms contained in the PHYLIP package (Felsenstein, 2002). Bootstrap analysis by means of 1000 resamplings was used to evaluate tree topologies (Felsenstein, 1985). DNADNA hybridization was performed using the optical renaturation method (De Ley et al., 1970; Huß et al., 1983; Jahnke, 1992) with three replications.

The DNA G + C content of strain JSM $076093^{\mathrm{T}}$ was $38.8 \mathrm{~mol} \%$. An almost-complete $16 \mathrm{~S}$ rRNA gene sequence (1482 bp) was determined. The phylogenetic analysis revealed that strain JSM $076093^{\mathrm{T}}$ should be assigned to the genus Bacillus and that it was most closely related to $B$. hwajinpoensis SW-72 ${ }^{\mathrm{T}}$ (99.1\% $16 \mathrm{~S}$ rRNA gene sequence similarity; Yoon et al., 2004) and B. algicola KMM $3737^{\mathrm{T}}$ (97.3\%; Ivanova et al., 2004). Less than $95.0 \%$ sequence similarity was observed with members of other species of the genus Bacillus. The neighbour-joining tree confirmed that strain JSM $076093^{\mathrm{T}}$ was phylogenetically closely related to the genus Bacillus. Strain JSM 076093 ${ }^{\mathrm{T}}$ formed a robust lineage ( $100 \%$ bootstrap support) with $B$. hwajinpoensis SW- $-72^{\mathrm{T}}$ and B. algicola KMM $3737^{\mathrm{T}}$ (Fig. 1). Similar topologies were obtained in trees constructed using the maximumlikelihood and maximum-parsimony methods (Supplementary Fig. S1, available in IJSEM Online). DNA-DNA relatedness between strain JSM $076093^{\mathrm{T}}$ and B. hwajinpoensis DSM $16206^{\mathrm{T}}$ and B. algicola KCTC $13005^{\mathrm{T}}$ was $($ mean \pm SD) $30.7 \pm 3.2$ and $10.5 \pm 1.5 \%$, respectively, which is well below the $70 \%$ threshold value recommended by Wayne et al. (1987) for the definition of species. Therefore, on the basis of phylogenetic analysis and DNA-DNA relatedness and in accordance with accepted criteria (Wayne et al., 1987; Stackebrandt \& Goebel, 1994), it would appear that strain JSM $076093^{\mathrm{T}}$ represents a novel species of the genus Bacillus.

Amino acids of whole-cell hydrolysates were analysed as described by Hasegawa et al. (1983). Isoprenoid quinones were analysed by HPLC as described by Groth et al. (1996). Polar lipids were extracted according to the method of Minnikin et al. (1979) and identified by two-dimensional TLC and spraying with appropriate detection reagents (Collins \& Jones, 1980). Fatty acids were determined for strain JSM $076093^{\mathrm{T}}$ and the reference strains according to Sasser (1990), using the Microbial Identification System (Microbial ID) with cells grown in marine broth 2216 (Difco) in a rotary shaker (200 r.p.m.) at $30{ }^{\circ} \mathrm{C}$ for 2 days.

The chemotaxonomic data for strain JSM $076093^{\mathrm{T}}$ were consistent with the assignment of strain JSM $076093^{\mathrm{T}}$ to the genus Bacillus. Strain JSM $076093^{\mathrm{T}}$ possessed a cell-wall type based on meso-diaminopimelic acid as the diagnostic diamino acid. The isolate contained MK-7 (95.8\%) as the predominant menaquinone, with MK-6 (1.5\%) and MK-8 $(2.7 \%)$ present in minor amounts. The polar lipids consisted of diphosphatidylglycerol, phosphatidylethanolamine, phosphatidylglycerol and one unidentified phospholipid (Supplementary Fig. S2). The fatty acid profile of strain JSM $076093^{\mathrm{T}}$ was similar to those of the reference strains, although there were differences in the proportions of some components (Table 2). The major fatty acids were anteiso- $\mathrm{C}_{15: 0}(47.5 \%)$, anteiso- $\mathrm{C}_{17: 0}(12.9 \%)$, iso- $\mathrm{C}_{16: 0}$ $(12.8 \%)$ and iso- $\mathrm{C}_{14: 0}(9.0 \%)$, which are characteristic of many members within the genus Bacillus (Kämpfer, 1994).

The results of the phylogenetic analysis and the morphological and chemotaxonomic investigations supported the affiliation of strain JSM $076093^{\mathrm{T}}$ to the genus Bacillus. However, the abilities to grow under anaerobic conditions,

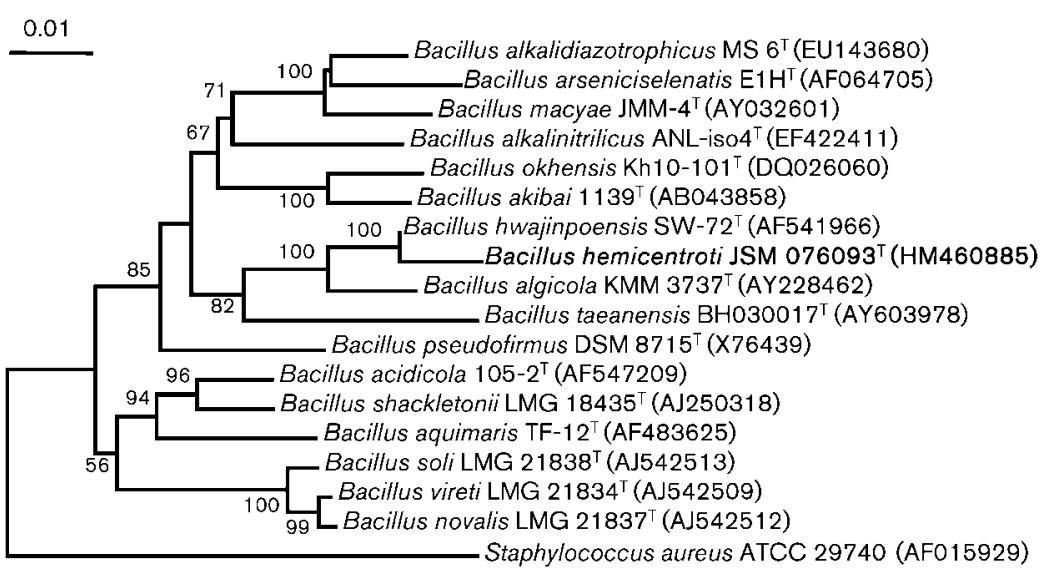

Fig. 1. Neighbour-joining phylogenetic tree based on 16S rRNA gene sequences showing the positions of strain JSM $076093^{\top}$ and closely related members of the genus Bacillus. Bootstrap values ( $>50 \%$ ) based on 1000 resampled datasets are shown at branch nodes. Bar, 1 substitution per 100 nucleotides. 
Table 2. Fatty acid compositions of strain JSM $076093^{\top}$ and related species of the genus Bacillus

Strains: 1, JSM $076093^{\mathrm{T}} ; 2$, B. hwajinpoensis DSM $16206^{\mathrm{T}} ; 3, B$. algicola $\mathrm{KCTC} 13005^{\mathrm{T}}$. All data were taken from this study.

\begin{tabular}{|c|c|c|c|}
\hline Fatty acid (\%) & 1 & 2 & 3 \\
\hline \multicolumn{4}{|l|}{ Saturated } \\
\hline $\mathrm{C}_{14: 0}$ & 0.6 & 0.2 & 0.4 \\
\hline $\mathrm{C}_{16: 0}$ & 6.0 & 0.5 & 1.0 \\
\hline $\mathrm{C}_{18: 0}$ & 0.9 & 0.1 & 0.2 \\
\hline \multicolumn{4}{|l|}{ Unsaturated } \\
\hline $\mathrm{C}_{16: 1} \omega 7 c$ alcohol & 2.8 & 10.0 & 3.3 \\
\hline $\mathrm{C}_{16: 1} \omega 11 c$ & 1.2 & 0.4 & 0.2 \\
\hline $\mathrm{C}_{18: 1} \omega 9 c$ & 0.6 & 0.2 & 0.3 \\
\hline \multicolumn{4}{|l|}{ Branched } \\
\hline anteiso- $\mathrm{C}_{13: 0}$ & 0.2 & 0.2 & - \\
\hline iso- $\mathrm{C}_{13: 0}$ & - & - & 0.7 \\
\hline iso- $\mathrm{C}_{14: 0}$ & 9.0 & 31.0 & 7.6 \\
\hline iso- $\mathrm{C}_{15: 0}$ & 3.5 & 6.8 & 11.7 \\
\hline anteiso- $\mathrm{C}_{15: 0}$ & 47.5 & 30.3 & 50.2 \\
\hline iso- $\mathrm{C}_{16: 0}$ & 12.8 & 16.8 & 14.0 \\
\hline iso- $\mathrm{C}_{17: 0}$ & 0.9 & 0.6 & 2.3 \\
\hline anteiso- $\mathrm{C}_{17: 0}$ & 12.9 & 2.5 & 6.1 \\
\hline \multicolumn{4}{|l|}{ Summed features ${ }^{*}$} \\
\hline 3 & 0.4 & 0.1 & 0.2 \\
\hline 4 & 0.3 & 0.3 & 0.3 \\
\hline
\end{tabular}

*Summed features represent two or three fatty acids that cannot be separated by the Microbial Identification System. Summed feature 3 consisted of $\mathrm{C}_{16: 1} \omega 7 c$ and/or $\mathrm{C}_{16: 1} \omega 6 c$. Summed feature 4 consisted of iso- $\mathrm{C}_{17: 1} \mathrm{I}$ and/or anteiso- $\mathrm{C}_{17: 1} \mathrm{~B}$.

ferment glucose and grow with up to $25 \%(\mathrm{w} / \mathrm{v}) \mathrm{NaCl}$, as well as the colony pigmentation, the positive result for the methyl red test and several other phenotypic characteristics, clearly differentiated the isolate from its closest phylogenetic relatives. In conclusion, strain JSM $076093^{\mathrm{T}}$ represents a novel species of the genus Bacillus, for which we propose the name Bacillus hemicentroti sp. nov.

\section{Description of Bacillus hemicentroti sp. nov.}

Bacillus hemicentroti [he.mi.cen.tro'ti. N.L. gen. n. hemicentroti of Hemicentrotus (Hemicentrotus pulcherrimus, a sea urchin), the source of isolation of the organism].

Cells are Gram-staining-positive, catalase-positive, oxidase-negative, non-motile, facultatively anaerobic, straight rods, approximately $0.6-0.9 \mu \mathrm{m}$ wide and $2.5-3.5 \mu \mathrm{m}$ long, occurring singly, as pairs or as short chains and producing ellipsoidal endospores that lie in subterminal unswollen or slightly swollen sporangia. Colonies are yellow, flat and opaque, have smooth surfaces and circular margins and are 3-4 mm in diameter on MA supplemented with $3 \%(\mathrm{w} / \mathrm{v})$ $\mathrm{NaCl}$. No diffusible pigments are produced. Moderately halophilic and facultatively alkaliphilic; growth occurs with $0.5-25 \%(w / v) ~ \mathrm{NaCl}$ (optimum 5-8\%), at pH 6.0-10.5 (optimum $\mathrm{pH} 8.0$ ) and at $5-40{ }^{\circ} \mathrm{C}$ (optimum $30-35{ }^{\circ} \mathrm{C}$ ).
Nitrate is reduced to nitrite, but nitrite is not reduced further. Positive for glucose fermentation, methyl red test and urease, but negative for phenylalanine deaminase, $\mathrm{H}_{2} \mathrm{~S}$ and indole production and the Voges-Proskauer test. Aesculin, casein, gelatin, starch and Tweens 20, 40 and 60 are hydrolysed, but cellulose, DNA, hypoxanthine, Tween 80 and xanthine are not. Acids are produced from Larabinose, D-fructose, D-glucose, glycogen, maltose, Dmannose, melibiose, raffinose, starch, sucrose, D-mannitol and D-sorbitol, but not from cellobiose, D-galactose, lactose, melezitose, L-rhamnose, D-ribose, trehalose, Dxylose, amygdalin, D-salicin, adonitol, dulcitol, glycerol, myo-inositol or $\mathrm{N}$-acetylglucosamine. As sole sources of carbon or carbon and nitrogen, utilizes L-arabinose, dextrin, D-fructose, D-glucose, maltose, melibiose, D-ribose, sucrose, D-mannitol, gluconate, L-alanine and L-asparagine, but not cellobiose, D-galactose, glycogen, lactose, Dmannose, melezitose, raffinose, L-rhamnose, trehalose, Dxylose, amygdalin, D-salicin, adonitol, D-arabitol, glycerol, myo-inositol, D-sorbitol, acetate, butyrate, citrate, propionate, succinate, $\mathrm{N}$-acetylglucosamine, L-arginine, L-glutamic acid, glycine, L-histidine, hydroxy-L-proline, L-isoleucine, L-leucine, L-methionine, L-phenylalanine, L-proline, Lserine or L-valine. Constitutive enzymes are acid and alkaline phosphatases, $\alpha$-chymotrypsin, esterase (C4), esterase lipase (C8), $\beta$-galactosidase, $\alpha$-glucosidase, leucine arylamidase and naphthol-AS-BI-phosphohydrolase, but not cystine arylamidase, $\alpha$-fucosidase, $\alpha$-galactosidase, $\beta$ glucosidase, $N$-acetyl- $\beta$-glucosaminidase, $\beta$-glucuronidase, lipase (C14), $\alpha$-mannosidase, trypsin or valine arylamidase. meso-Diaminopimelic acid is present in the cell-wall peptidoglycan as the diagnostic diamino acid. Possesses MK-7 as the predominant menaquinone and diphosphatidylglycerol, phosphatidylethanolamine, phosphatidylglycerol and one unidentified phospholipid as the polar lipids. The major fatty acids are anteiso- $\mathrm{C}_{15: 0}$, anteiso$\mathrm{C}_{17: 0}$, iso- $\mathrm{C}_{16: 0}$ and iso- $\mathrm{C}_{14: 0}$.

The type strain, JSM $076093^{\mathrm{T}}\left(=\mathrm{DSM} 23007^{\mathrm{T}}=\right.$ KCTC $\left.13710^{\mathrm{T}}\right)$, was isolated from a homogenate of a sea urchin (Hemicentrotus pulcherrimus) collected from Naozhou Island in the South China Sea. The DNA G + C content of the type strain is $38.8 \mathrm{~mol} \%$ (HPLC).

\section{Acknowledgements}

This work was supported by grants from the National Basic Research Program of China (2010CB833800), National Natural Science Foundation of China (NSFC) (30970007, 30970008), state-level public welfare scientific research institutes for basic R\&D special fund (IMBF200915) and International Cooperation Research Program of Yunnan Province (2009AC017). We are grateful to $\mathrm{Mr}$ Zhu-Xiang Liu and $\mathrm{Mr} \mathrm{Ke}$ Huang for their excellent technical assistance.

\section{References}

Aizawa, T., Urai, M., Iwabuchi, N., Nakajima, M. \& Sunairi, M. (2010). Bacillus trypoxylicola sp. nov., xylanase-producing alkaliphilic bacteria 
isolated from the guts of Japanese horned beetle larvae (Trypoxylus dichotomus septentrionalis). Int J Syst Evol Microbiol 60, 61-66.

Arahal, D. R. \& Ventosa, A. (2002). Moderately halophilic and halotolerant species of Bacillus and related genera. In Applications and Systematics of Bacillus and Relatives, pp. 83-99. Edited by R. C. W. Berkeley, M. Heyndrickx, N. Logan \& P. De Vos. Oxford: Blackwell.

Ash, C., Farrow, J. A. E., Wallbanks, S. \& Collins, M. D. (1991). Phylogenetic heterogeneity of the genus Bacillus as revealed by comparative analysis of small-subunit ribosomal-RNA sequences. Lett Appl Microbiol 13, 202-206.

Atlas, R. M. (1993). Handbook of Microbiological Media. Edited by L. C. Parks. Boca Raton, FL: CRC Press.

Baik, K. S., Lim, C. H., Park, S. C., Kim, E. M., Rhee, M. S. \& Seong, C. N. (2010). Bacillus rigui sp. nov., isolated from wetland fresh water. Int J Syst Evol Microbiol 60, 2204-2209.

Balcázar, J. L., Pintado, J. \& Planas, M. (2010). Bacillus galliciensis sp. nov., isolated from faeces of wild seahorses (Hippocampus guttulatus). Int J Syst Evol Microbiol 60, 892-895.

Chen, Y.-G., Cui, X.-L., Pukall, R., Li, H.-M., Yang, Y.-L., Xu, L.-H., Wen, M.-L., Peng, Q. \& Jiang, C.-L. (2007). Salinicoccus kunmingensis sp. nov., a moderately halophilic bacterium isolated from a salt mine in Yunnan, south-west China. Int J Syst Evol Microbiol 57, 2327-2332.

Chen, Y.-G., Zhang, Y.-Q., Shi, J.-X., Xiao, H.-D., Tang, S.-K., Liu, Z.-X., Huang, K., Cui, X.-L. \& Li, W.-J. (2009a). Jeotgalicoccus marinus sp. nov., a marine bacterium isolated from a sea urchin. Int J Syst Evol Microbiol 59, 1625-1629.

Chen, Y.-G., Zhang, Y.-Q., Xiao, H.-D., Liu, Z.-X., Yi, L.-B., Shi, J.-X., Zhi, X.-Y., Cui, X.-L. \& Li, W.-J. (2009b). Pontibacillus halophilus sp. nov., a moderately halophilic bacterium isolated from a sea urchin. Int J Syst Evol Microbiol 59, 1635-1639.

Chen, Y.-G., Zhang, Y.-Q., Wang, Y.-X., Liu, Z.-X., Klenk, H.-P., Xiao, H.-D., Tang, S.-K., Cui, X.-L. \& Li, W.-J. (2009c). Bacillus neizhouensis sp. nov., a halophilic marine bacterium isolated from a sea anemone. Int J Syst Evol Microbiol 59, 3035-3039.

Chen, Y.-G., Zhang, Y.-Q., Yi, L.-B., Li, Z.-Y., Wang, Y.-X., Xiao, H.-D., Chen, Q.-H., Cui, X.-L. \& Li, W.-J. (2010). Pontibacillus litoralis sp. nov., a facultatively anaerobic bacterium isolated from a sea anemone, and emended description of the genus Pontibacillus. Int J Syst Evol Microbiol 60, 560-565.

Cho, S.-L., Jung, M. Y., Park, M.-H. \& Kim, W. (2010). Bacillus chungangensis sp. nov., a halophilic species isolated from sea sand. Int J Syst Evol Microbiol 60, 1349-1352.

Chun, J., Lee, J.-H., Jung, Y., Kim, M., Kim, S., Kim, B. K. \& Lim, Y.-W. (2007). EzTaxon: a web-based tool for the identification of prokaryotes based on $16 \mathrm{~S}$ ribosomal RNA gene sequences. Int J Syst Evol Microbiol 57, 2259-2261.

Collins, M. D. \& Jones, D. (1980). Lipids in the classification and identification of coryneform bacteria containing peptidoglycans based on 2,4-diaminobutyric acid. J Appl Bacteriol 48, 459-470.

Cowan, S. T. \& Steel, K. J. (1965). Manual for the Identification of Medical Bacteria. London: Cambridge University Press.

Cui, X.-L., Mao, P.-H., Zeng, M., Li, W.-J., Zhang, L.-P., Xu, L.-H. \& Jiang, C.-L. (2001). Streptimonospora salina gen. nov., sp. nov., a new member of the family Nocardiopsaceae. Int J Syst Evol Microbiol 51, 357-363.

De Ley, J., Cattoir, H. \& Reynaerts, A. (1970). The quantitative measurement of DNA hybridization from renaturation rates. Eur $J$ Biochem 12, 133-142.

Denizci, A. A., Kazan, D. \& Erarslan, A. (2010). Bacillus marmarensis sp. nov., an alkaliphilic, protease-producing bacterium isolated from mushroom compost. Int J Syst Evol Microbiol 60, 1590-1594.
Euzéby, J. P. (2010). List of bacterial names with standing in nomenclature - genus Bacillus: a folder available on the Internet. [Last full update 29 December 2010]. http://www.bacterio.cict.fr/b/bacillus. html.

Felsenstein, J. (1981). Evolutionary trees from DNA sequences: a maximum likelihood approach. J Mol Evol 17, 368-376.

Felsenstein, J. (1985). Confidence limits on phylogenies: an approach using the bootstrap. Evolution 39, 783-791.

Felsenstein, J. (2002). PHYLIP (phylogeny inference package) version 3.6a. Distributed by the author. Department of Genome Sciences, University of Washington, Seattle, USA.

Gregersen, T. (1978). Rapid method for distinction of Gram-negative from Gram-positive bacteria. Eur J Appl Microbiol Biotechnol 5, 123127.

Groth, I., Schumann, P., Weiss, N., Martin, K. \& Rainey, F. A. (1996). Agrococcus jenensis gen. nov., sp. nov., a new genus of actinomycetes with diaminobutyric acid in the cell wall. Int J Syst Bacteriol 46, 234239.

Hasegawa, T., Takizawa, M. \& Tanida, S. (1983). A rapid analysis for chemical grouping of aerobic actinomycetes. J Gen Appl Microbiol 29, 319-322.

Hopwood, D. A., Bibb, M. J., Chater, K. F., Kieser, T., Bruton, C. J., Kieser, H. M., Lydiate, D. J., Smith, C. P. \& Ward, J. M. (1985). Genetic Manipulation of Streptomyces: a Laboratory Manual. Norwich: John Innes Foundation.

Horikoshi, K. (1999). Alkaliphiles: some applications of their products for biotechnology. Microbiol Mol Biol Rev 63, 735-750.

Huang, K., Zhang, L., Liu, Z., Chen, Q., Peng, Q., Li, W., Cui, X. \& Chen, Y. (2009). [Diversity of culturable bacteria associated with the sea urchin Hemicentrotus pulcherrimus from Naozhou Island]. Wei Sheng Wu Xue Bao 49, 1424-1429 (in Chinese).

Huß, V. A. R., Festl, H. \& Schleifer, K. H. (1983). Studies on the spectrophotometric determination of DNA hybridization from renaturation rates. Syst Appl Microbiol 4, 184-192.

Ivanova, E. P., Alexeeva, Y. A., Zhukova, N. V., Gorshkova, N. M., Buljan, V., Nicolau, D. V., Mikhailov, V. V. \& Christen, R. (2004). Bacillus algicola sp. nov., a novel filamentous organism isolated from brown alga Fucus evanescens. Syst Appl Microbiol 27, 301-307.

Jahnke, K. D. (1992). BASIC computer program for evaluation of spectroscopic DNA renaturation data from Gilford System 2600 spectrophotometer on a PC/XT/AT type personal computer. J Microbiol Methods 15, 61-73.

Kämpfer, P. (1994). Limits and possibilities of total fatty acid analysis for classification and identification of Bacillus species. Syst Appl Microbiol 17, 86-98.

Kimura, M. (1980). A simple method for estimating evolutionary rates of base substitutions through comparative studies of nucleotide sequences. J Mol Evol 16, 111-120.

Kluge, A. G. \& Farris, F. S. (1969). Quantitative phyletics and the evolution of anurans. Syst Zool 18, 1-32.

Krulwich, T. A., Hicks, D. B., Swartz, T. H. \& Ito, M. (2007). Bioenergetic adaptations that support alkaliphily. In Physiology and Biochemistry of Extremophiles, pp. 311-329. Edited by C. Gerday \& N. Glansdorff. Washington, DC: American Society for Microbiology.

Kumar, S., Tamura, K. \& Nei, M. (2004). MEGA3: integrated software for molecular evolutionary genetics analysis and sequence alignment. Brief Bioinform 5, 150-163.

Logan, N. A., Berge, O., Bishop, A. H., Busse, H.-J., De Vos, P., Fritze, D., Heyndrickx, M., Kämpfer, P., Rabinovitch, L. \& other authors (2009). Proposed minimal standards for describing new taxa of aerobic, endospore-forming bacteria. Int J Syst Evol Microbiol 59, 2114-2121. 
Madhaiyan, M., Poonguzhali, S., Kwon, S.-W. \& Sa, T.-M. (2010). Bacillus methylotrophicus sp. nov., a methanol-utilizing, plant-growthpromoting bacterium isolated from rice rhizosphere soil. Int J Syst Evol Microbiol 60, 2490-2495.

Margesin, R. \& Schinner, F. (2001). Potential of halotolerant and halophilic microorganisms for biotechnology. Extremophiles 5, 73-83.

Mesbah, M., Premachandran, U. \& Whitman, W. B. (1989). Precise measurement of the $\mathrm{G}+\mathrm{C}$ content of deoxyribonucleic acid by highperformance liquid chromatography. Int J Syst Bacteriol 39, 159-167.

Minnikin, D. E., Collins, M. D. \& Goodfellow, M. (1979). Fatty acid and polar lipid composition in the classification of Cellulomonas, Oerskovia and related taxa. J Appl Bacteriol 47, 87-95.

Nielsen, P., Rainey, F. A., Outtrup, H., Priest, F. A. \& Fritze, D. (1994). Comparative $16 \mathrm{~S}$ rDNA sequence analysis of some alkaliphilic bacilli and the establishment of a sixth rRNA group within the genus Bacillus. FEMS Microbiol Lett 117, 61-65.

Nogi, Y., Takami, H. \& Horikoshi, K. (2005). Characterization of alkaliphilic Bacillus strains used in industry: proposal of five novel species. Int J Syst Evol Microbiol 55, 2309-2315.

Pappa, A., Sánchez-Porro, C., Lazoura, P., Kallimanis, A. Perisynakis, A., Ventosa, A., Drainas, C. \& Koukkou, A. I. (2010). Bacillus halochares sp. nov., a halophilic bacterium isolated from a solar saltern. Int J Syst Evol Microbiol 60, 1432-1436.

Saitou, N. \& Nei, M. (1987). The neighbor-joining method: a new method for reconstructing phylogenetic trees. Mol Biol Evol 4, 406425.

Sasser, M. (1990). Identification of bacteria by gas chromatography of cellular fatty acids, MIDI Technical Note 101. Newark, DE: MIDI Inc.

Smibert, R. M. \& Krieg, N. R. (1994). Phenotypic characterization. In Methods for General and Molecular Bacteriology, pp. 607-654. Edited by P. Gerhardt, R. G. E. Murray, W. A. Wood \& N. R. Krieg. Washington, DC: American Society for Microbiology.

Stackebrandt, E. \& Goebel, B. M. (1994). Taxonomic note: a place for DNA-DNA reassociation and 16S rRNA sequence analysis in the present species definition in bacteriology. Int J Syst Bacteriol 44, 846-849.
Stackebrandt, E. \& Liesack, W. (1993). Nucleic acids and classification. In Handbook of New Bacterial Systematics, pp. 152-189. Edited by M. Goodfellow \& A. G. O’Donnell. London: Academic Press.

Sumpavapol, P., Tongyonk, L., Tanasupawat, S., Chokesajjawatee, N., Luxananil, P. \& Visessanguan, W. (2010). Bacillus siamensis sp. nov., isolated from salted crab (poo-khem) in Thailand. Int J Syst Evol Microbiol 60, 2364-2370.

Thompson, J. D., Gibson, T. J., Plewniak, F., Jeanmougin, F. \& Higgins, D. G. (1997). The CLUSTAL_X windows interface: flexible strategies for multiple sequence alignment aided by quality analysis tools. Nucleic Acids Res 25, 4876-4882.

Vaishampayan, P., Probst, A., Krishnamurthi, S., Ghosh, S., Osman, S., McDowall, A., Ruckmani, A., Mayilraj, S. \& Venkateswaran, K. (2010). Bacillus horneckiae sp. nov., isolated from a spacecraft-assembly clean room. Int J Syst Evol Microbiol 60, 1031-1037.

Ventosa, A., Quesada, E., Rodriguez-Valera, F., Ruiz-Berraquero, F. \& Ramos-Cormenzana, A. (1982). Numerical taxonomy of moderately halophilic Gram-negative rods. J Gen Microbiol 128, 1959-1968.

Ventosa, A., Nieto, J. J. \& Oren, A. (1998). Biology of moderately halophilic aerobic bacteria. Microbiol Mol Biol Rev 62, 504-544.

Wayne, L. G., Brenner, D. J., Colwell, R. R., Grimont, P. A. D., Kandler, O., Krichevsky, M. I., Moore, L. H., Moore, W. E. C., Murray, R. G. E. \& other authors (1987). International Committee on Systematic Bacteriology. Report of the ad hoc committee on reconciliation of approaches to bacterial systematics. Int J Syst Bacteriol 37, 463-464.

Xiao, H.-D., Chen, Y.-G., Liu, Z.-X., Huang, K., Li, W.-J., Cui, X.-L., Zhang, L. \& Yi, L.-B. (2009). [Phylogenetic diversity of cultivable bacteria associated with a sea anemone from coast of the Naozhou island in Zhanjiang, China]. Wei Sheng Wu Xue Bao 49, 246-250 (in Chinese).

Yoon, J.-H., Kim, I.-G., Kang, K. H., Oh, T.-K. \& Park, Y.-H. (2004). Bacillus hwajinpoensis sp. nov. and an unnamed Bacillus genomospecies, novel members of Bacillus rRNA group 6 isolated from sea water of the East Sea and the Yellow Sea in Korea. Int J Syst Evol Microbiol 54, 803-808.

Zhang, J., Wang, J., Fang, C., Song, F., Xin, Y., Qu, L. \& Ding, K. (2010). Bacillus oceanisediminis sp. nov., isolated from marine sediment. Int J Syst Evol Microbiol 60, 2924-2929. 